\title{
Using a Hierarchical Approach to Calibrate SWAT and Predict the Semi-Arid Hydrologic Regime of Northeastern Brazil
}

\author{
Carlos A. S. Santos 1,2, , Carina Almeida ${ }^{2}$, Tiago B. $\operatorname{Ramos}^{2}$ (D), Felizardo A. Rocha ${ }^{1}$, \\ Rodrigo Oliveira ${ }^{3}$ and Ramiro Neves 2 (iD \\ 1 Engineering Department, Instituto Federal da Bahia, Bahia 45030-220, Brazil; felizardo@ifba.edu.br \\ 2 Centro de Ciência e Tecnologia do Ambiente e do Mar (MARETEC), Instituto Superior Técnico, \\ Universidade de Lisboa, Lisboa 1049-001, Portugal; carina.almeida@tecnico.ulisboa.pt (C.A.); \\ tiagobramos@tecnico.ulisboa.pt (T.B.R.); ramiro.neves@tecnico.ulisboa.pt (R.N.) \\ 3 Instituto Superior Técnico, Universidade de Lisboa, Lisboa 1049-001, Portugal; \\ rodrigopoliveira@tecnico.ulisboa.pt \\ * Correspondence: carlos.amilton@ifba.edu.br or carlos.amilton@tecnico.ulisboa.pt
}

Received: 13 July 2018; Accepted: 23 August 2018; Published: 25 August 2018

\begin{abstract}
The Paraguaçu watershed in northeastern Brazil faces increasing water scarcity, with water resources unable to meet the increasing demand. Accurate assessment of water availability is thus essential for efficient planning and management of local resources. In this work, the potential of the SWAT model for predicting daily and monthly variability of the hydrologic regime of the Paraguaçu River was assessed. Model calibration/validation followed: (i) A hierarchical framework; (ii) the assessment of maximum, average and minimum streamflow based on paired t-test and linear regression analysis; and (iii) the definition of permanence curves for streamflow with a probability of occurrence of 90\% (Q90) and 95\% (Q95). The goodness-of-fit indicators revealed a "satisfactory" model performance (model efficiency ranged from 0.42 to 0.83 ) when predicting streamflow in monitored sub-basins using a unique set of parameters for wet and dry conditions. The flow duration curves also showed that the model underestimated higher flows resulting from extreme events but performed well for flows with exceedance probabilities of $<90 \%$. The regression analysis and paired t-test demonstrated that the SWAT model can be used for estimating maximum, average and minimum monthly streamflow in a region where information is insufficient to support water authorities in the decision-making process. The SWAT model can thus be considered adequate for simulating monthly streamflow in the Paraguaçu watershed.
\end{abstract}

Keywords: hydrologic process; semiarid; Paraguaçu watershed; hierarchical scheme; SWAT

\section{Introduction}

The Paraguaçu watershed in northeastern Brazil faces increasing water scarcity due to population growth, agriculture consumption and climate change. The watershed is an essential part of Bahia's fluvial system, with reservoirs supplying water to approximately 3.9 million people. Accurate assessment of streamflow at the watershed scale is of vital importance since the current seasonal and interannual discharge of the Paraguaçu River has not been able to meet the existing demand for water [1]. In this context, quantitative understanding of hydrological parameters (rainfall and streamflow) and their spatial and temporal variability are essential for an efficient planning and management of local water resources [2].

Hydrological modeling is normally considered as a powerful tool for accurately estimating water availability at the watershed scale. Physically-based hydrological models have shown to be particularly 
suitable for simulating basin response to changing conditions, including climate variability, land use and management practices [3-5]. The Soil and Water Assessment Tool (SWAT) [6] is here a good example, being widely applied to assess the impact of climate and land management on hydrological processes, including streamflow and sediment and nutrient dynamics at the watershed scale [7-9]. However, its application to the Brazilian semiarid region has been rather scarce, although interest has been rising in recent years.

The application of the SWAT model is often particularly challenging due to the need for calibrating a large number of parameters which aim to describe the processes under analysis. The most common approach used in model calibration is by optimizing its parameters until deviations between predictions and historical observation data are minimized. Validation then follows, with predictions being again compared with an independent dataset to assess the reliability of the optimized model parameters. Klemeš [10] discussed different validation tests and proposed a hierarchical testing framework in which different approaches are ordered according to the possibility of transferring model results to different land uses, climate and other forms of environmental changes. These calibration/validation tests are divided in four major categories: (i) The Split Sample test, in which the model is calibrated using data from a period and then applied with the same calibrated parameters for simulating a different period (validation); (ii) the Differential Split-Sample test, where the same approach is followed but data is divided in two periods with varying climate characteristics (e.g., high/low average precipitation); (iii) the Proxy-basin test, where the model is calibrated and validated in various sites, which may be in the same basin or not but with similar edapho-climatic characteristics; and (iv) the Proxy-Basin Differential Split-Sample test, which is applied in cases where the model is supposed to be both geographically and climatically (or land-use-wise) transposable.

While the SWAT model has been applied in many Brazilian watersheds, model calibration/validation has followed simple approaches that have limited its use in improving water resources management and planning at the watershed scale, namely in the Paraguaçu watershed. The choice of the hydrological model and the calibration/validation process is fundamental for the reliability of model results and for improving the decision-making process at the basin scale. It is necessary to emphasize that the longer the time interval used for calibrating/validating the model, the more reliable the results are [11]. This is especially true for studies of land use/cover and climate change conducted in semiarid regions where water resources management is even more critical and necessary. As such, few reliable studies exist for the Paraguaçu basin having carried out a comprehensive calibration and validation of the modeled processes, using different techniques and especially considering time periods of more than ten years.

The objective of this study was thus to verify the potential of the SWAT model for predicting the hydrologic regime and its possible use in the planning and management of streamflow in the Paraguaçu River basin. In this research, the SWAT model was calibrated/validated using different approaches: (i) The hierarchical scheme proposed by Klemeš [10]; (ii) the assessment of the maximum, average and minimum streamflow based on the paired t-test and linear regression analysis [12]; and (iii) the analysis of the permanence curve for the Q90 and Q95 flows. The evaluation techniques were tested in the three sub-basins of the Paraguaçu upstream region (Andaraím Fortém and Iguaçu), considering calibration/validation periods of not less than ten years and considering daily and monthly timescales. Results will allow improving water resources management and planning in the Paraguaçu watershed, with the calibration approach being transferable to other semiarid regions in the world.

\section{Material and Methods}

\subsection{Study Area}

The Paraguaçu watershed is located in the Bahia state, northeastern Brazil (Figure 1). The basin covers an area of $55,317 \mathrm{~km}^{2}$ (10.14\% of the territory) and has an altitude ranging from 0 to $1800 \mathrm{~m}$ $\left(11^{\circ} 17^{\prime}-13^{\circ} 36^{\prime} \mathrm{S} ; 38^{\circ} 50^{\prime}-42^{\circ} 01^{\prime} \mathrm{W}\right)$. The Paraguaçu River is $614 \mathrm{~km}$ long, flowing in the west-east 
direction towards "Todos os Santos" bay. According to the Köppen classification, the climate in the Paraguaçu River Basin varies from semi-arid (BSh) in the central part (67\% of the area) to equatorial (Af) in the west and southeast areas. As a result, annual rainfall varies between less than $600 \mathrm{~mm}$ in the former area to $1400 \mathrm{~mm}$ in the latter regions [13]. The Paraguaçu River further constitutes the most important fluvial system in the Bahia state and includes five reservoirs: Pedra do Cavalo (with a storage capacity of $\left.5330 \mathrm{hm}^{3}\right)$, Bandeira de Melo $\left(318 \mathrm{hm}^{3}\right)$, Apertado $\left(204 \mathrm{hm}^{3}\right)$, França $\left(59 \mathrm{hm}^{3}\right)$ and São José do Jacuípe $\left(355 \mathrm{hm}^{3}\right)$.

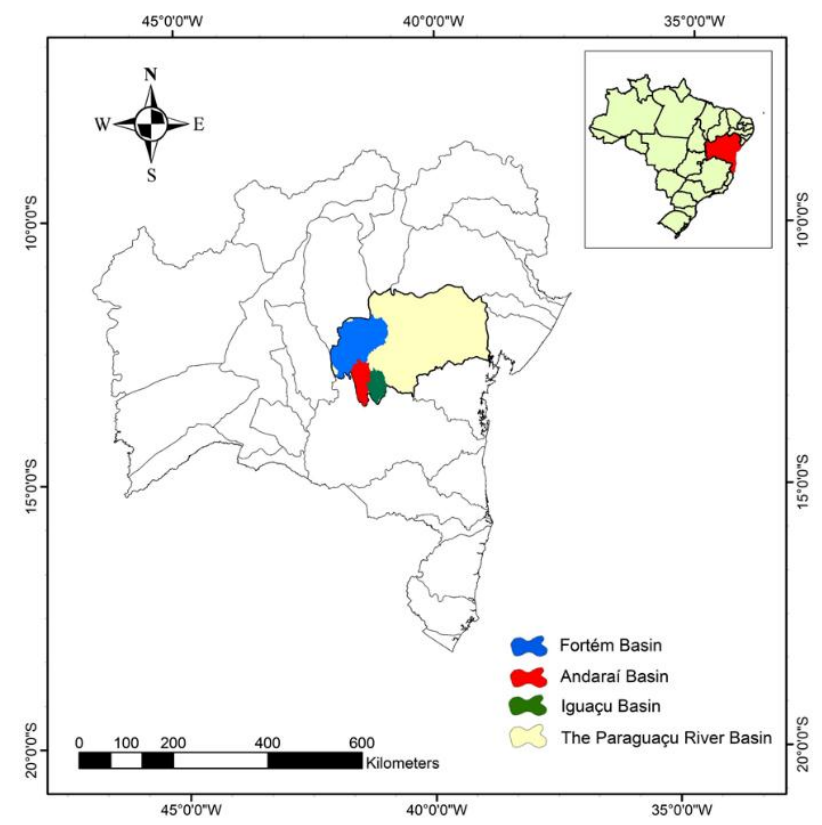

Figure 1. Localization of the Paraguaçu watershed and study area.

The Paraguaçu watershed is composed of three regions: High, medium and low Paraguaçu River Basin. The study area was included in the high Paraguaçu $\left(13,774 \mathrm{~km}^{2}\right)$ region, being defined by three sub-basins: Andaraí (2313 km²), Iguaçu $\left(2034 \mathrm{~km}^{2}\right)$ and Fortém $\left(9426 \mathrm{~km}^{2}\right)$ (Figure 1). The Andaraí sub-basin is characterized by more intense agriculture activity than in the remaining sub-basins. The average annual precipitation value is also higher in Andaraí $(866 \mathrm{~mm})$ than in Fortém $(788 \mathrm{~mm})$ or Iguaçu $(701 \mathrm{~mm})$. The soil in the sub-basins are Ferrosols $(77.15 \%)$, Lithic Leptosol $(21.72 \%)$ and Regosols (1.14\%) [14]. The main land-uses are pasture (26.0\%), deciduous forest (21.0\%), cerrado $(19.5 \%)$, caatinga (19.0\%), mixed forest (13.0\%) and agriculture (1.5\%) (Table 1; Figure 2$)$.

Table 1. Land use in the Andaraí, Iguaçu and Fortém sub-basins.

\begin{tabular}{ccccccccc}
\hline Basin & $\begin{array}{c}\text { AREA } \\
\mathbf{( k m}^{\mathbf{2}}\end{array}$ & $\begin{array}{c}\text { PAST } \\
\mathbf{( \% )}\end{array}$ & $\begin{array}{c}\text { SWRN } \\
\mathbf{( \% )}\end{array}$ & $\begin{array}{c}\text { FRST } \\
\mathbf{( \% )}\end{array}$ & $\begin{array}{c}\text { FRSD } \\
\mathbf{( \% )}\end{array}$ & $\begin{array}{c}\text { RNGE } \\
\mathbf{( \% )}\end{array}$ & $\begin{array}{c}\text { RNGB } \\
\mathbf{( \% )}\end{array}$ & $\begin{array}{c}\text { AGRR } \\
(\mathbf{\%})\end{array}$ \\
\hline Andaraí & 2313.80 & 24.58 & 3.96 & 4.59 & 3.26 & 22.14 & 34.64 & 6.82 \\
Iguaçu & 2034.03 & 26.50 & 15.63 & 22.58 & 10.48 & 24.40 & 0.24 & 0.17 \\
Fortém & 9426.50 & 25.81 & 22.98 & 12.87 & 27.62 & 0.34 & 10.11 & 0.27 \\
\hline
\end{tabular}

PAST, pasture; SWRN, caatinga; FRST, mixed forest; FRSD, deciduous forest; RNGE, cerrado, RNGB, bushes cerrado; AGRR, agricultural land. 

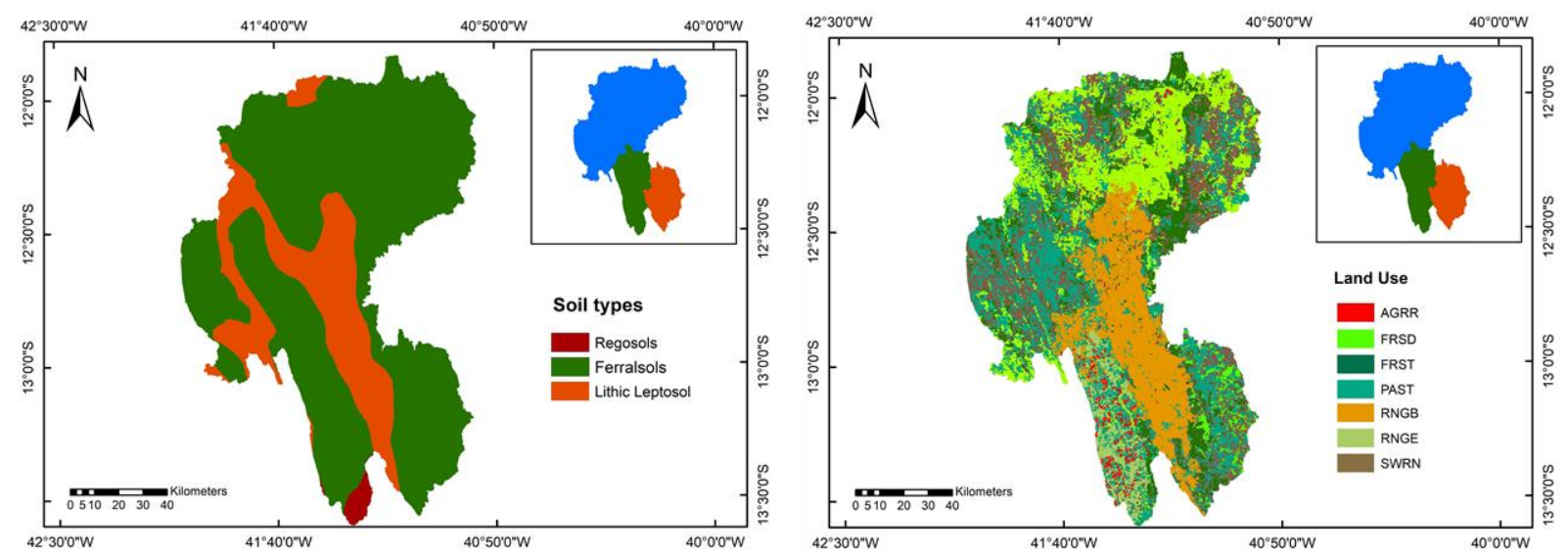

Figure 2. Soil and Land use maps of the High Paraguaçu region.

\subsection{Soil and Water Assessment Tool}

The SWAT (Soil and Water Assessment Tool) model version 2012 [6] was used to simulate the soil water balance between 1993 and 2012. SWAT is a continuous, time-dependent, long-term, physically based, semi-distributed model, developed to assess the impacts of climate and land management on hydrological processes, sediment loading and pollution transport. The hydrologic cycle is based on the computation of the daily water balance, as follows:

$$
\mathrm{SW}_{\mathrm{t}}=\mathrm{SW}_{0}+\sum_{\mathrm{i}=1}^{\mathrm{t}}\left(\mathrm{R}_{\text {day }}-\mathrm{Q}_{\text {surf }}-\mathrm{ET}_{\mathrm{a}}-\mathrm{Q}_{\text {deep }}-\mathrm{Q}_{\mathrm{gw}}\right)
$$

where $S_{W}$ is the final soil water content $(\mathrm{mm}), \mathrm{SW}_{0}$ is the initial soil water content $(\mathrm{mm}), t$ is the simulation period (days), $R_{\text {day }}$ is the precipitation $(\mathrm{mm}), \mathrm{Q}_{\text {surf }}$ is the surface runoff $(\mathrm{mm}), \mathrm{ET}_{\mathrm{a}}$ is the actual evapotranspiration $(\mathrm{mm}), Q_{\text {deep }}$ is the water drained into the deep aquifer $(\mathrm{mm})$ and $\mathrm{Q}_{\mathrm{gw}}$ is the return flow $(\mathrm{mm})$, all referring to day $i$.

The overall water balance is generated at the hydrologic response units (HRUs) level, that is, areas with the same land-use and soil characteristics [6]. In this study, potential evapotranspiration (ETp rates were estimated using the Penman-Monteith method [15] and partitioned into potential plant transpiration $\left(T_{p}\right)$ and potential soil evaporation $\left(E_{p}\right)$ rates based on Ritchie [16]. Surface runoff was computed from daily precipitation using a modification of the Soil Conservation Service Curve Number (SCS-CN) method [17]. Groundwater recharge was estimated by combining a storage routing technique and a crack-flow model. The lateral flow was simulated using a kinematic storage method [6].

\subsection{Model Data Inputs}

The digital elevation model (DEM) was obtained from the Shuttle Radar Topography Mission (SRTM), with a spatial resolution of $30 \mathrm{~m}$ (Figure 3). Daily precipitation, maximum and minimum temperature, relative humidity, solar radiation and wind speed were used in model simulations for computing streamflow and evapotranspiration rates. Precipitation data were obtained from Agência Nacional de Águas (ANA), while the remaining weather variables were taken from the Instituto Nacional de Meteorologia (INMET) (Table 2). Quality control assessment for precipitation and streamflow data can be found in ANA [18]. The grid of meteorological variables from Xavier et al. [19] was also used due to the high rain spatial variability and a small number of pluviometric stations in the region. The daily discharge data at Andaraí, Iguaçu and Fortém hydrometric stations (Table 3) were obtained from Agência Nacional de Águas (ANA), while the extraction of water volumes from the river channel and reservoirs were taken from the Instituto de Meio Ambiente e Recursos Hídricos da Bahia [20]. The soil map (Figure 2) was downloaded from Empresa Brasileira de Pesquisas Agropecúarias [14], while the soil's physical and chemical properties were collected from 
local literature [21-24]. The land cover map was obtained from Globcover 2009 [25]. The Brazilian Institute of Geography and Statistics-IBGE [26] — provided the crop information for the Mucugê and Ibicoará irrigated areas (Andarai basin) between 2004 and 2012. These regions represent the largest irrigated area of the Paraguaçu watershed.

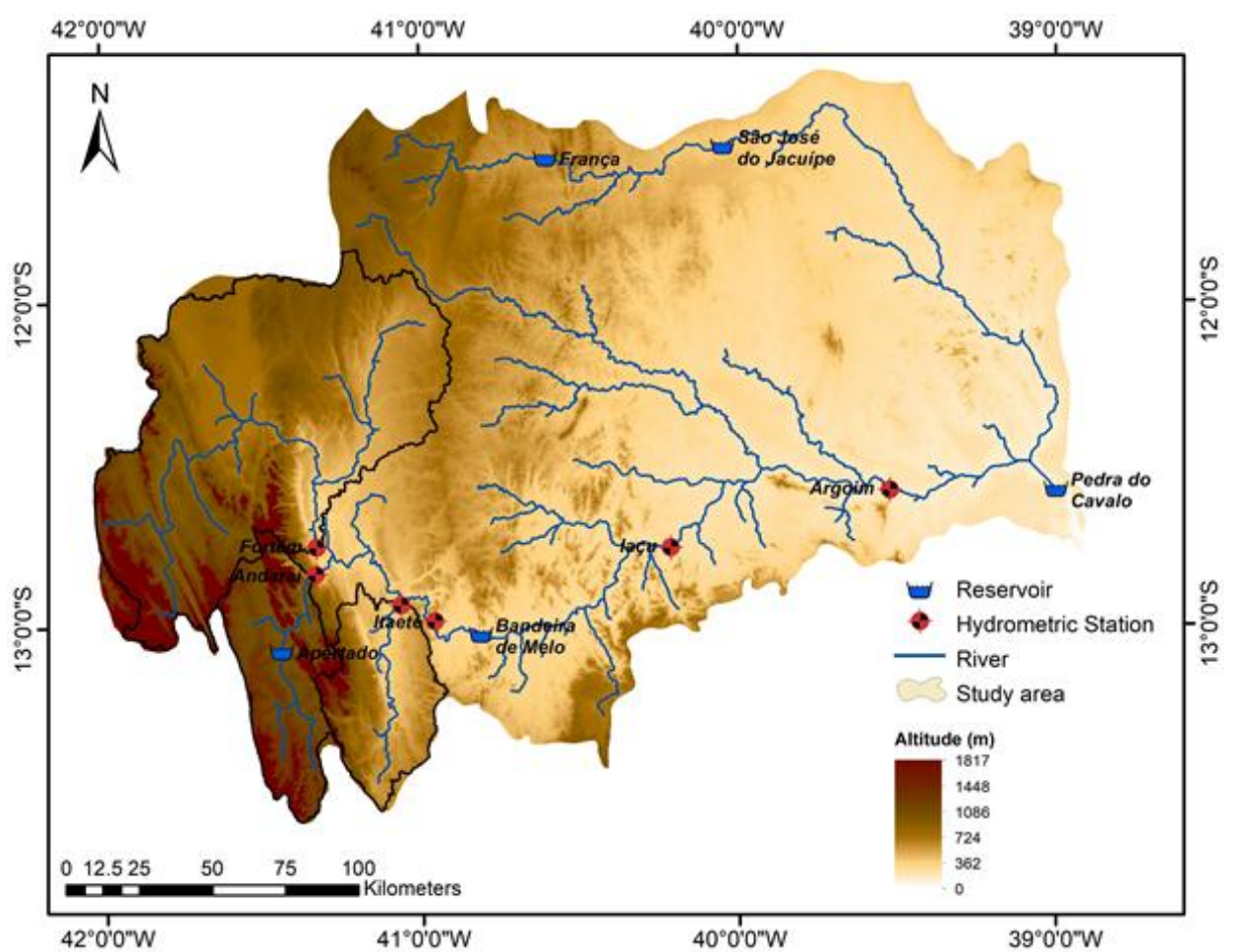

Figure 3. Digital elevation model of the Paraguaçu watershed. Location of reservoirs and hydrometric stations.

Table 2. Location of pluviometric and weather stations and sensors used for monitoring weather variables.

\begin{tabular}{|c|c|c|c|c|c|c|}
\hline \multirow{2}{*}{ Station } & \multirow[b]{2}{*}{ Code } & \multirow{2}{*}{ Entity } & \multicolumn{2}{|c|}{ Coordinates } & \multirow[b]{2}{*}{ Altitude (m) } & \multirow[b]{2}{*}{ Sensors } \\
\hline & & & Latitude $\left({ }^{\circ}\right)$ & Longitude $\left({ }^{\circ}\right)$ & & \\
\hline Andaraí * & 1241008 & ANA & -12.80 & -41.33 & 330 & raingauge $(0.1 \mathrm{~mm})$ \\
\hline Usina Mucugê * & 1241033 & ANA & -13.01 & -41.37 & 870 & raingauge $(0.1 \mathrm{~mm})$ \\
\hline Lençóis ** & 83242 & INMET & -12.57 & -41.38 & 439 & $* * *$ \\
\hline Faz-Ribeiro* & 1241027 & ANA & -12.06 & -41.12 & 450 & raingauge $(0.1 \mathrm{~mm})$ \\
\hline Utinga * & 1241028 & ANA & -12.50 & -41.21 & 357 & raingauge $(0.1 \mathrm{~mm})$ \\
\hline
\end{tabular}

* Pluviometric station; ${ }^{* *}$ Meteorological station; ${ }^{* * *}$ sensors can be assessed at http://www.inmet.gov.br/portal/ index.php? $\mathrm{r}=$ home $/$ page\&page=instrumentos.

Table 3. Location of the hydrometric station and sensors used for monitoring river discharge.

\begin{tabular}{ccccc}
\hline \multirow{2}{*}{ Station } & \multirow{2}{*}{ Code } & \multicolumn{2}{c}{ Coordinates } & \\
& & Latitude $\left(^{\circ}\right)$ & Longitude $\left(^{\circ}\right)$ & \multirow{2}{*}{ Sensors } \\
\hline Andaraí & 51120000 & -12.84 & -41.33 & Pressure transducers $(1 \mathrm{~cm})$ \\
Iguaçu & 51230000 & -12.93 & -41.06 & Pressure transducers $(1 \mathrm{~cm})$ \\
Fortém & 51190000 & -12.76 & -41.33 & Pressure transducers $(1 \mathrm{~cm})$ \\
\hline
\end{tabular}




\subsection{Calibration and Validation}

The SWAT model calibration/validation was carried out for daily and monthly timesteps, by comparing simulated and observed streamflows following a hierarchical approach proposed by Klemeš [10]. The following tests were performed:

(1) Split Sample Test: This test was carried out in the Andaraí basin. Two-time periods were selected for this analysis: a calibration period (1989-2001) and a validation period (2002-2013). Before, the model was warmed up using the data set from 1985-1988. This test included wet and dry years, being defined for civil years with average annual precipitation above and below the average for the 1989-2013 period (866 $\mathrm{mm} \cdot$ year $\left.^{-1}\right)$, respectively.

(2) Differential split-sample test: This test was also performed in the Andaraí basin and consisted of calibrating streamflow during wet years and validating it during dry years and vice versa. Two data periods were selected: the wet period from 2004-2006 and the dry period from 2007-2013. This test is required whenever a model is to be used for simulating the effect of climate change [27]. If the climatic change corresponds to a transition to a warmer wetter scenario, the model should be calibrated on a dry cool data set and then validated for the other extreme. Due to the temporal variation of the precipitation regime (Figure 4), the dataset chosen for the dry period included two years where precipitation was above the average $\left(866 \mathrm{~mm} \cdot \mathrm{year}^{-1}\right)$. A comparison between the first (2004-2006) and second (2007-2013) half of data series showed that the mean monthly precipitation decreased from 96 to $61 \mathrm{~mm}$ (Figure 4), corresponding to a reduction of $36 \%$.

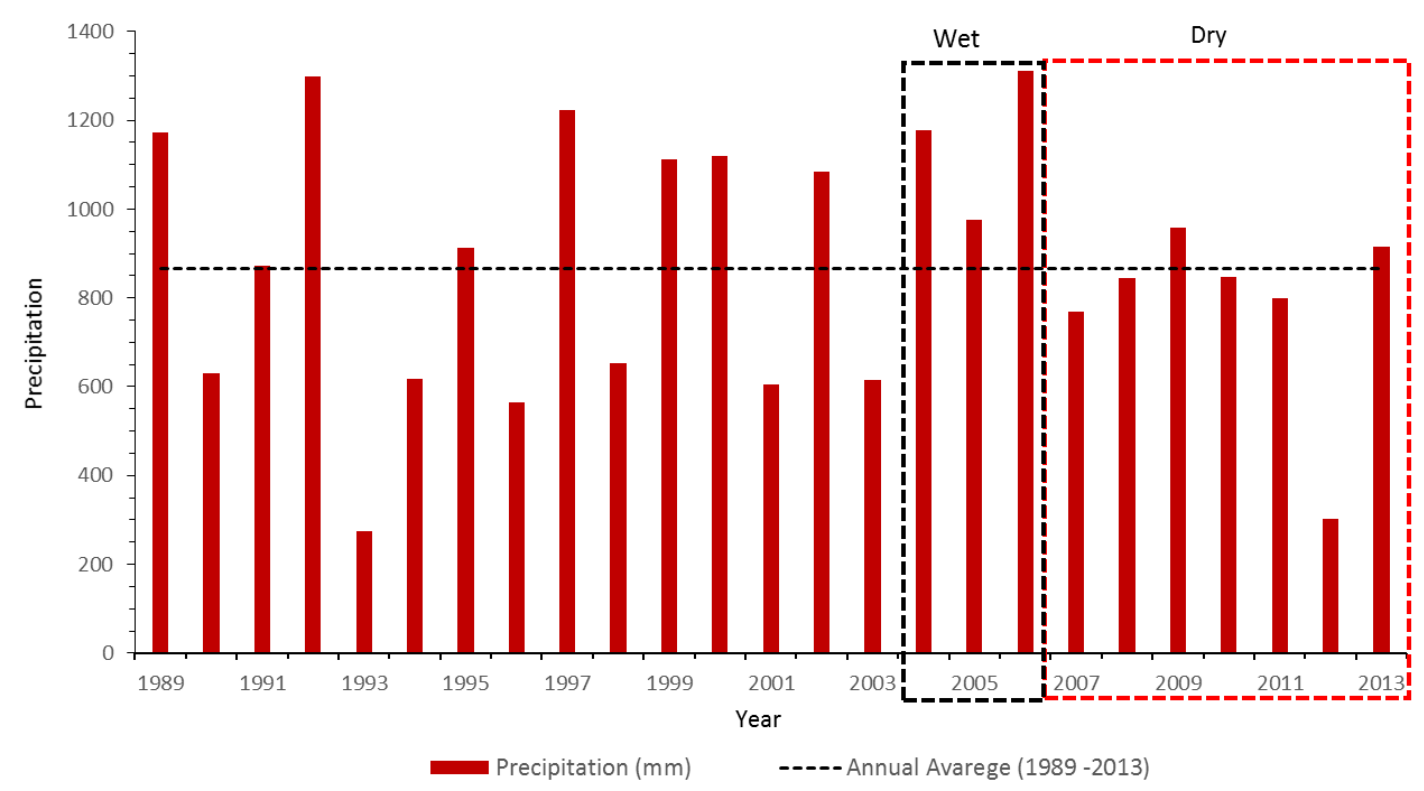

Figure 4. Annual precipitation values for the Andarai sub-basin during 1989-2013. Wet and Dry periods chosen for the differential split-sample test.

(3) Proxy-Basin Test: The Iguaçu and Fortém sub-basins were selected as having similar land use characteristics as those in Andaraí. The model was first calibrated in the Andaraí sub-basin and validated in Iguaçu and Fortém sub-basins. This test allowed to evaluate the model's ability in predicting the impacts of land use changes in a region where flow data does not exist [10].

(4) Proxy-Basin differential split-sample Test: The model was first calibrated for wet conditions in the Andaraí sub-basin and then used to simulate streamflow for dry conditions in the Iguaçu basin and vice versa. Both watersheds share similar characteristics. The wet and dry years were identified from historical records, with the model being calibrated on three wet years (2004-2006) and validated on seven drier years (2007-2013) like before. 
For each test, the SWAT model was calibrated by manually modifying one factor at a time with the aim of finding the set of factors that determined the best results in terms of global water balance in the basin (Table 4). The hydrograms were analyzed and the parameters that affected flow peaks and baseflow-that is, the behavior of the flow curve-were selected and modified until deviations between model outputs and measured flow data were minimized. The previously calibrated parameters were then validated by comparing results of simulations with an independent measurement set. Four commonly used goodness-of-fit indicators were used to evaluate model performance: the determination coefficient $\left(\mathrm{R}^{2}\right)$, the percent bias (PBIAS), the ratio of the root mean square error to the standard deviation of measured data (RSR) and the Nash-Sutcliffe model efficiency (NSE) [28], as follows:

$$
\begin{gathered}
\mathrm{R}^{2}=\frac{\left[\sum_{\mathrm{i}=1}^{\mathrm{n}}\left(\mathrm{O}_{\mathrm{i}}-\overline{\mathrm{O}}\right)\left(\mathrm{P}_{\mathrm{i}}-\overline{\mathrm{P}}\right)\right]^{2}}{\sum_{\mathrm{i}=1}^{\mathrm{n}}\left(\mathrm{O}_{\mathrm{i}}-\overline{\mathrm{O}}\right)^{2} \sum_{\mathrm{i}=1}^{\mathrm{n}}\left(\mathrm{P}_{\mathrm{i}}-\overline{\mathrm{P}}\right)^{2}} \\
\text { PBIAS }=\left[\frac{\sum_{\mathrm{i}=1}^{\mathrm{n}}\left(\mathrm{O}_{\mathrm{i}}-\mathrm{P}_{\mathrm{i}}\right)}{\sum_{\mathrm{i}=1}^{\mathrm{n}}\left(\mathrm{O}_{(\mathrm{i})}\right)} * 100\right] \\
\text { RSR }=\frac{\sqrt{\sum_{\mathrm{i}=1}^{\mathrm{n}}\left(\mathrm{O}_{\mathrm{i}}-\mathrm{P}_{\mathrm{i}}\right)^{2}}}{\sqrt{\sum_{\mathrm{i}=1}^{\mathrm{n}}\left(\mathrm{O}_{\mathrm{i}}-\overline{\mathrm{P}}\right)^{2}}} \\
\text { NSE }=1-\left[\frac{\sum_{\mathrm{i}=1}^{\mathrm{n}}\left(\mathrm{O}_{\mathrm{i}}-\mathrm{P}_{\mathrm{i}}\right)^{2}}{\sum_{\mathrm{i}=1}^{\mathrm{n}}\left(\mathrm{O}_{\mathrm{i}}-\overline{\mathrm{O}}\right)^{2}}\right]
\end{gathered}
$$

where $\mathrm{P}$ is the model simulated values, $\mathrm{O}$ is the observed data, the over bar describes the mean for the entire period of the evaluation, $\mathrm{n}$ is the number of data pairs and $i=1,2, \ldots, \mathrm{n} . \mathrm{R}^{2}$ is an indicator of the strength of the relationship between the observed and simulated values and varies between 0 and $1 . R^{2}$ values $>0.5$ are regarded as acceptable for model simulation [29]. The PBIAS measures the tendency of the simulated data to be larger or smaller than their observed counterparts. PBIAS values $<10 \%$ are considered very good; values from $10 \%<$ PBIAS $<15 \%$ are considered good; values from \pm $15 \%<$ PBIAS $<25 \%$ are considered satisfactory and $\geq 25 \%$ are unsatisfactory [29]. RSR incorporates the benefits of error index statistics and includes a scaling/normalization factor, so that the resulting statistic and reported values can apply to various constituents. RSR varies from the optimal value of 0 , which indicates zero RMSE or residual variation and therefore perfect model simulation, to a large positive value. For monthly values, RSR values $\leq 0.5$ are considered very good; values from $0.50<$ PBIAS $<0.60$ are considered good; values from $0.60<$ PBIAS $<0.70$ are considered satisfactory; and values $>0.70$ are considered unsatisfactory [29]. The NSE is a normalized statistic that determines the relative magnitude of the model variance compared to the measured data variance, ranging from 1 to $-\infty$. A NSE value of 1 corresponds to the best fit between simulated and measured data; values $>0.75$ are considered excellent; values between 0.36 and 0.75 are considered satisfactory; and values $<0.36$ are unsatisfactory [29].

Additionally, streamflow data was submitted to the Kolmogorov-Smirnov ( $\mathrm{p}<0.05)$ normality test. Considering that the data presented normal distribution, the parametric T-paired test was used to verify the hypothesis that the observed and simulated flow data did not present a significant difference between them $(p<0.05)$ [12]. The data analysis further consisted of comparing simulated and observed streamflow values within each quartile to assess the ability of the model in describing the maximum, average and minimum streamflow. Governmental institutions generally use the first quartile (the lowest $25 \%$ of monthly streamflow) as a reference in assessing water resource availability for multiple uses. 
Table 4. Default and calibrated parameters used in model simulations.

\begin{tabular}{cccc}
\hline Parameter & Description & Default & Calibrated Value \\
\hline GW_DELAY & Groundwater Delay (days) & $0-500$ & $31-365$ \\
GW_REVAP & Revaporation coefficient (-) & $0.02-0.2$ & $0.02-0.2$ \\
GW_RCHRG_DP & Deep aquifer recharge (mm) & $0-1$ & $0.05-0.25$ \\
Mgt1_CN2 & SCS runoff curve number for moisture & $35-89$ & $45-78$ \\
HRU_SLSOIL & condition II (-) & $0-150$ & $0-85$ \\
SOL_AWC & Hillslope length (m) & $0.075-0.40$ & $0.1-0.30$ \\
SOL_Z & Available water capacity of the soil layer & - & $500-3000$ \\
SOL_K & (mm/mm soil) & - & $2-35$ \\
CH_K2 & Soil depth $(\mathrm{mm})$ & $0.01-1.5$ \\
\hline
\end{tabular}

\section{Results and Discussion}

\subsection{Model Calibration and Validation}

Table 4 lists the default and calibrated parameters used in model simulations of the water balance in the Paraguaçu River basin. The SWAT model was shown to be highly sensitive to surface runoff parameters (CN2, SOL_AWC, SOL_Z and SOL_K), in line with Neitsch et al. [6], who stated that these were some of the most sensitive parameters for river discharge simulations. The available water capacity of the soil layer (SOL_AWC), saturated hydraulic conductivity (SOL_K) and soil depth (SOL_Z) influenced soil moisture and thus surface runoff. The CN2 default values of 35-89 were calibrated to the range 45-78, which is still in line with USDA-SCS [17]. The greatest uncertainties were found in soil parameters due to the large spatial variability observed in the basin as well as the difficulties in obtaining accurate and reliable soil information; a common limitation in most regions of the world. For example, SOL_K was made to vary between 2-35 mm/h, while SOL_AWC suffered a relative large change with inputs being considered reliable nonetheless as soils in the region have coarse to medium textures in the top layers [14]. The calibration of groundwater flow and baseflow ended up being controlled by groundwater delay (GW_DELAY), revaporation coefficient (GW_REVAP) and deep aquifer recharge (GW_RCHRG_DP) parameters. Reducing GW_DELAY affected both the width of the peak discharge and quantity of water available for base flow [6]. GW_REVAP controlled the amount of water moving from the shallow aquifer to the root zone as a result of soil moisture depletion and the amount of direct groundwater uptake from deep-rooted trees and shrubs [6]. GW_RCHRG_DP controlled percolation from the root zone to the deep aquifer. Finally, the effective hydraulic conductivity of the main channel (CH_K2) governed the movement of water from streambed to the subsurface for ephemeral or transient streams, which, according to Veith et al. [30], is a highly sensitive parameter when the watershed is characterized by intense and inconsistent precipitation events like in the Andaraí sub-basin. Nonetheless, despite a relatively extensive model calibration, all parameters were adjusted within their physical meaning, indicating the reasonability of model inputs.

\subsubsection{Split-Sample Test}

The Split-Sample Test was carried out by first separating different time periods for calibration and validation purposes. For daily and monthly scales, the dataset was split in half (Figure 5), with the first 50\% intending for calibration (1989-2001) while the remaining 50\% being left for validation (2002-2013). Simulation started on January 1985 and included four years for model warmup. 


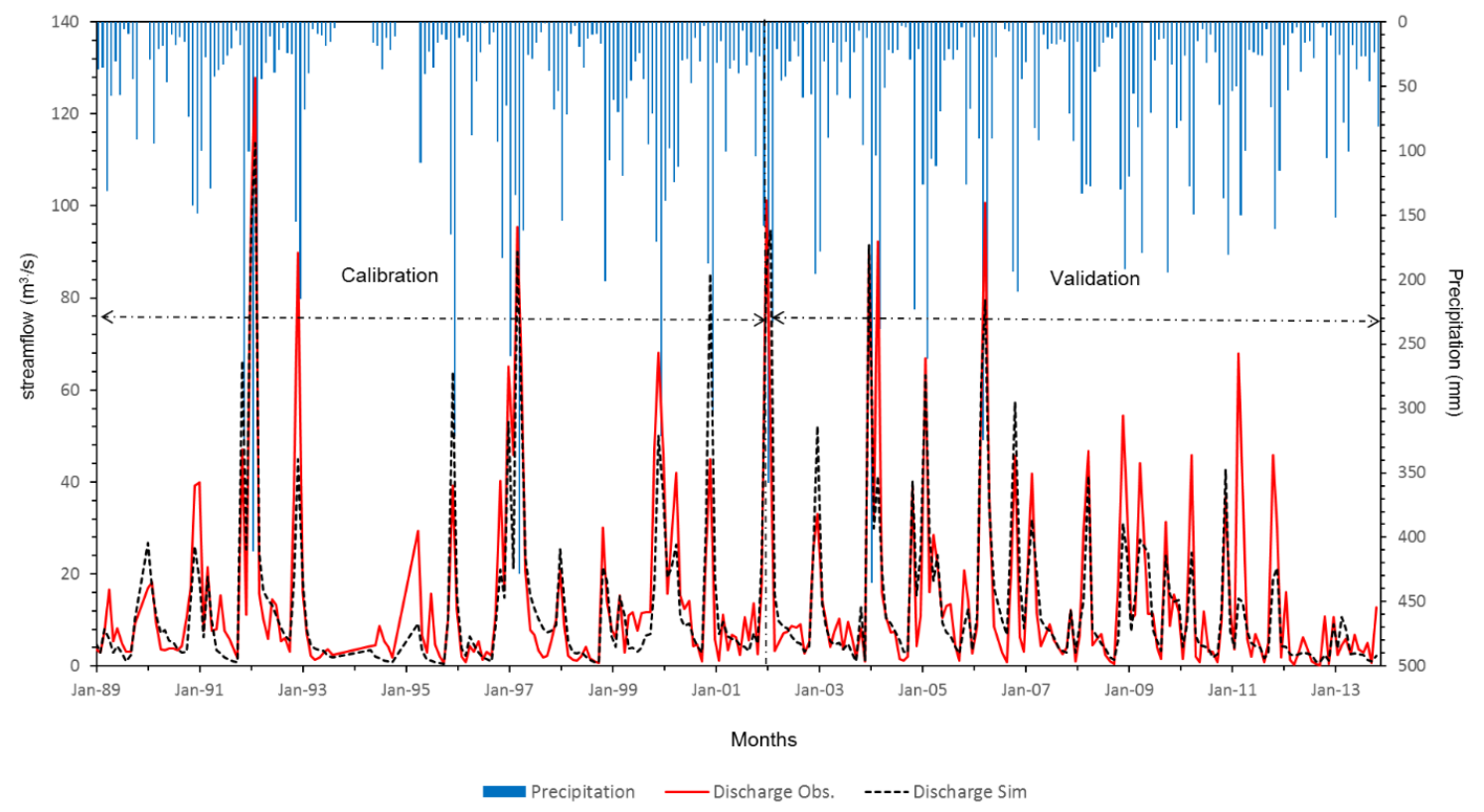

Figure 5. Monthly simulated and observed streamflow values in the Andaraí sub-basin (calibration: 1989-2001; validation: 2002-2013).

Overall, the performance of the SWAT model was satisfactory, although underestimating streamflow peaks both during calibration and validation. The largest difference was found on March 2011 , where the model simulated values of $16.0 \mathrm{~m}^{3} / \mathrm{s}$ while the observed ones reached $68.0 \mathrm{~m}^{3} / \mathrm{s}$, that is, producing an error of $328 \%$ for that day. The underestimation of streamflow peaks was associated with the type of rainfall and representation of its spatial and temporal distribution. According to Vieira et al. [31], the precipitation that occurs in the region is orographic due to the high elevation observed in some areas of the watershed, while Cho et al. [32] refers that the sparse and heterogeneous spatial distribution of rain gauges often results in inaccurate precipitation inputs for SWAT, especially when modeling large river basins or those with different complex terrains like mountainous regions, where the assumption of spatially uniform rainfall is not valid.

For the Andaraí sub-basin, the NSE values calculated from daily results were 0.49 and 0.42 , while the monthly data produced values of 0.86 and 0.76 for the calibration and validation periods, respectively (Table 5). These values suggest a satisfactory model performance for daily predictions and an excellent performance for monthly estimates [29]. The $\mathrm{R}^{2}$ values were above 0.5 , indicating that the model explained the variability of the observed daily and monthly data. The PBIAS indicated slight deviations between the mean simulated and observed streamflow, showing that the model underestimated by $10 \%$ and $3-6 \%$ the daily and monthly observations during the calibration and validation periods, respectively. However, the RSR resulted in very good indicators $(R S R<0.5)$ for monthly flows. For daily simulations, RSR values were higher than 0.7 . Thus, the performance of the SWAT model in estimating the mean streamflow showed to be excellent for monthly flows, with all goodness-of-fit indicators being also within the range of values reported in the literature for similar applications using this model $[33,34]$. As such, the model could be considered fit for improving management of streamflow in the Paraguaçu watershed. 
Table 5. Goodness-of-fit indicators obtained after comparison of model simulations and measured values in the Andaraí sub-basin based on the split-sample test (NSE, model efficiency; PBIAS, percent bias; $\mathrm{R}^{2}$, coefficient of determination).

\begin{tabular}{ccccccccccc}
\hline \multirow{2}{*}{ Season } & \multicolumn{2}{c}{ Discharge Average $\left(\mathbf{m}^{\mathbf{3}} / \mathbf{s}\right)$} & \multicolumn{3}{c}{ Statistic Daily } & \multicolumn{4}{c}{ Statistic Monthly } \\
\cline { 2 - 11 } & Observed & Simulated & NSE & RSR & PBIAS & $\mathbf{R}^{\mathbf{2}}$ & NSE & RSR & PBIAS & $\mathbf{R}^{\mathbf{2}}$ \\
\hline $1989-2013$ & 15.11 & 13.88 & 0.45 & 0.74 & 8.2 & 0.53 & 0.79 & 0.45 & 6.30 & 0.79 \\
$1989-2001$ & 14.59 & 13.05 & 0.49 & 0.71 & 10.4 & 0.54 & 0.82 & 0.42 & 9.86 & 0.82 \\
$2002-2013$ & 15.62 & 14.72 & 0.42 & 0.76 & 6.0 & 0.52 & 0.76 & 0.49 & 3.41 & 0.76 \\
\hline
\end{tabular}

\subsubsection{Differential Split-Sample Test}

The primary requirement of the Differential split-sample test is a long record of simulation data from which different periods can be chosen which different historical conditions. For this test, the model adequately represented the behavior of the observed flows, underestimating peaks during both calibration and validation periods though (Figure 6), in line with existing literature [35,36]. The NSE values reached 0.47 and 0.50 for daily results and 0.83 and 0.63 for monthly outputs during the calibration and validation periods (Table 6), respectively, which means that the model was again found appropriate for simulating streamflow. Concerning the PBIAS, the model overestimated streamflow by $2-3 \%$ during wetter years (calibration) and underestimated streamflow by $17-20 \%$ during drier years (validation). Likewise, the RSR produced very good results for the monthly dry period but only satisfactory for the drier one. Nonetheless, the model was considered to operate under wet and dry conditions within acceptable margins of error. Muleta [37] revealed that SWAT-calibrated parameters for the headwaters of the Little River watershed were largely different between dry and wet periods. Li et al. [38] using another model found that model efficiency in the dry period was consistently lower than that in the wet period. Finally, Lévesque et al. [39] followed the seasonal calibration scheme in which winter and summer data were used to calibrate the model in two watersheds in southeastern Canada. Those authors reported that the best performance was obtained in the dry period using summer observations to calibrate the model; however, when the wet period observations were used, no advantage was achieved compared with the traditional calibration method based on all available data. Regarding the Andaraí sub-basin, calibrated parameters were found to be conservative while applying for wet or dry periods.

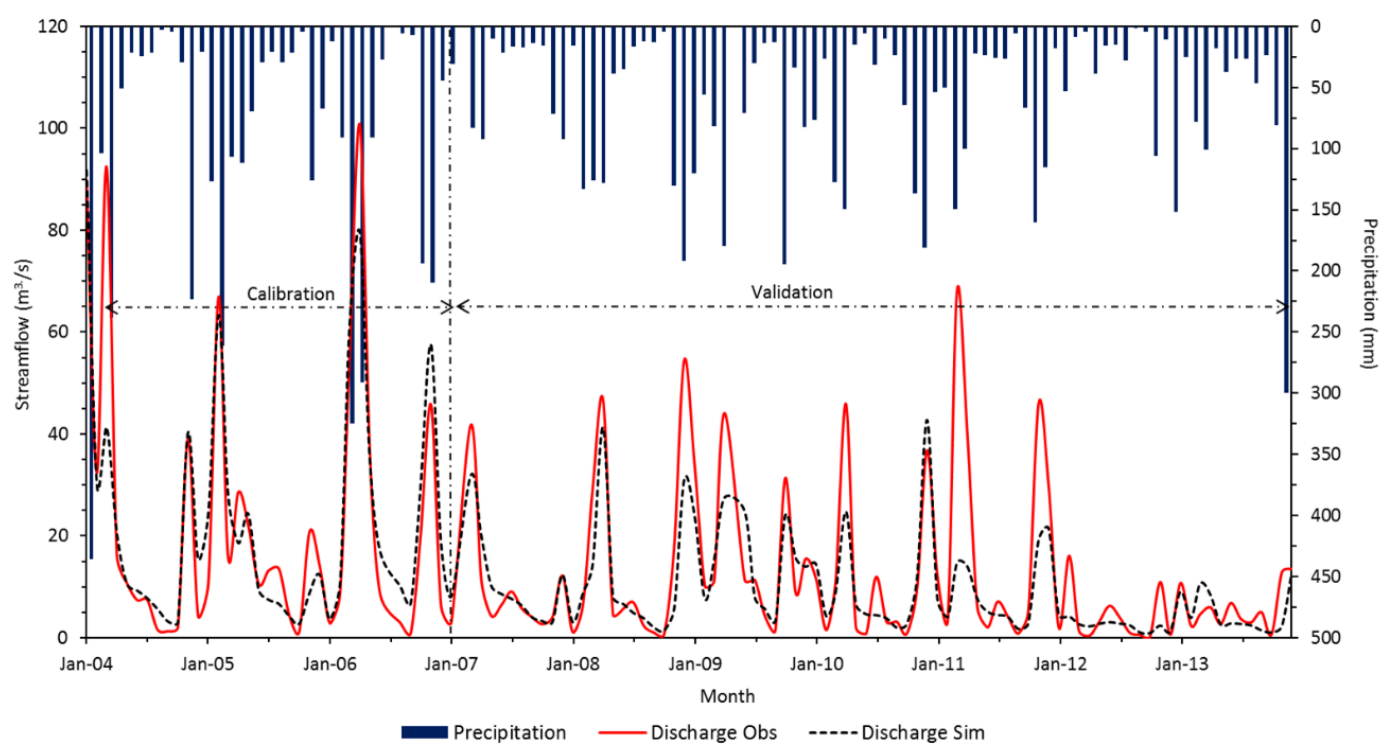

Figure 6. Monthly simulated and observed streamflow values in the Andaraí sub-basin (calibration: 2004-2006; validation: 2007-2013). 
Table 6. Goodness-of-fit indicators obtained after comparison of model simulations and measured values in the Andaraí sub-basin based on the differential split-sample test (NSE, model efficiency; PBIAS, percent bias; $\mathrm{R}^{2}$, coefficient of determination).

\begin{tabular}{cccccccccccc}
\hline \multirow{2}{*}{ Periods } & \multicolumn{3}{c}{ Discharge Average $\left(\mathbf{m}^{\mathbf{3}} / \mathbf{s}\right)$} & \multicolumn{3}{c}{ Statistic Daily } & \multicolumn{4}{c}{ Statistic Monthly } \\
\cline { 2 - 12 } & Observed & Simulated & NSE & RSR & PBIAS & $\mathbf{R}^{\mathbf{2}}$ & NSE & RSR & PBIAS & $\mathbf{R}^{\mathbf{2}}$ \\
\hline Wet (2004-2006) & 23.22 & 23.91 & 0.47 & 0.80 & -3.0 & 0.60 & 0.83 & 0.43 & -1.93 & 0.83 \\
Dry (2007-2013) & 12.77 & 10.20 & 0.50 & 0.70 & 20.2 & 0.51 & 0.63 & 0.61 & 16.5 & 0.66 \\
\hline
\end{tabular}

\subsubsection{Proxy-Catchment Test}

The Proxy-catchment test returned NSE values (Table 7) ranging from 0.44 (Iguaçu) to 0.36 (Fortém) for daily outputs, while monthly results produced NSE values ranging from 0.75 (Iguaçu) to 0.80 (Fortém). The daily and monthly PBIAS values ranged from $10-12 \%$ and $8.5-9.1 \%$ in Fortém and Iguaçu, respectively, indicating an underestimation of observed data in both basins. The RSR values showed again very good simulations of monthly flows. Thus, the model had an overall good satisfactory in Iguaçu and Fortém concerning monthly calibration data and an excellent performance to monthly validation data [29].

Table 7. Goodness-of-fit indicators obtained after comparison of model simulations and measured values in the Iguaçu and Fortém sub-basins (validation period 2002-2013) based on the proxy-catchment test (NSE, model efficiency; PBIAS, percent bias; $R^{2}$, coefficient of determination).

\begin{tabular}{ccccccccccc}
\hline \multirow{2}{*}{ Location } & \multicolumn{2}{c}{ Discharge Average $\left(\mathbf{m}^{\mathbf{3}} / \mathbf{s}\right)$} & \multicolumn{3}{c}{ Statistic Daily } & \multicolumn{4}{c}{ Statistic Monthly } \\
\cline { 2 - 10 } & Observed & Simulated & NSE & RSR & PBIAS & $\mathbf{R}^{\mathbf{2}}$ & NSE & RSR & PBIAS & $\mathbf{R}^{\mathbf{2}}$ \\
\hline Andaraí (calibration) & 14.59 & 13.05 & 0.49 & 0.72 & 10.4 & 0.54 & 0.82 & 0.45 & 9.86 & 0.82 \\
Iguaçu (validation) & 11.25 & 9.90 & 0.44 & 0.73 & 12.0 & 0.45 & 0.75 & 0.50 & 9.1 & 0.76 \\
Fortém (validation) & 19.89 & 17.88 & 0.36 & 0.82 & 10.0 & 0.45 & 0.80 & 0.44 & 8.6 & 0.83 \\
\hline
\end{tabular}

\subsubsection{Proxy-Catchment Differential Split-Sample Test}

This test was performed in the same catchments as in the previous test. Table 8 shows the satisfactory performance of the SWAT model for simulating streamflow in dry and wet periods. The monthly PBIAS values ranged from $8-21 \%$ in wet and dry periods, respectively, indicating always an underestimation of observed data. RSR values oscillated between very good and satisfactory results. On the other hand, the NSE values varied between 0.50 and 0.80 , indicating an acceptable model performance.

Table 8. Goodness-of-fit indicators obtained after comparison of model simulations and measured values in the Andaraí, Iguaçu and Fortém sub-basins based on the proxy-catchment differential split-sample test (NSE, model efficiency; PBIAS, percent bias; $\mathrm{R}^{2}$, coefficient of determination).

\begin{tabular}{ccccccccccc}
\hline \multirow{2}{*}{ Periods } & \multicolumn{2}{c}{ Discharge Average $\left(\mathbf{m}^{\mathbf{3}} / \mathbf{s}\right)$} & \multicolumn{3}{c}{ Statistic Daily } & \multicolumn{4}{c}{ Statistic Monthly } \\
\cline { 2 - 10 } & Observed & Simulated & NSE & RSR & PBIAS & $\mathbf{R}^{\mathbf{2}}$ & NSE & RSR & PBIAS & $\mathbf{R}^{\mathbf{2}}$ \\
\hline Andaraí-Wet & 23.22 & 23.91 & 0.47 & 0.80 & -3.0 & 0.60 & 0.83 & 0.41 & -1.93 & 0.83 \\
Iguaçu-Dry & 8.60 & 6.33 & 0.36 & 0.80 & 26.0 & 0.39 & 0.50 & 0.70 & 21.0 & 0.54 \\
Iguaçu-Wet & 18.08 & 16.86 & 0.47 & 0.72 & 6.7 & 0.48 & 0.80 & 0.46 & 8.10 & 0.83 \\
Andaraí-Dry & 12.77 & 10.20 & 0.50 & 0.70 & 20.2 & 0.51 & 0.63 & 0.61 & 16.5 & 0.66 \\
\hline
\end{tabular}

\subsubsection{Soil Water Balance}

After model calibration, the soil water balance was assessed to confirm the reliability of model estimates in the three simulated sub-basins (Table 9). Annual actual evapotranspiration was the main component of the soil water balance due to the characteristics of the semi-arid climate, varying between 69 and $86 \%$ of the total annual precipitation amount, in line with other semi-arid regions 
in the world [5,40-42]. $\mathrm{ET}_{\mathrm{a}}$ values further varied according to land use (Table 10) and obviously water availability. The highest $\mathrm{ET}_{\mathrm{a}}$ values were observed in Andaraí and Fortém due to the highest precipitation values registered. Yet, large variability was observed in $\mathrm{ET}_{\mathrm{a}}$ values, in line with precipitation. Runoff varied between 3.6 and $11.2 \%$ of the total annual precipitation amount, being fundamentally registered during storm events. Baseflow and lateral flow reached 7.4 to $14.3 \%$ of the total annual precipitation amount, being essential for maintaining river flow throughout the year. Similar results can be found in Bouraoui et al. [43].

Table 9. Soil water balance in Andaraí, Iguaçu and Fortém.

\begin{tabular}{ccccccc}
\hline & \multicolumn{3}{c}{ Total Amount $(\mathbf{m m})$} & \multicolumn{2}{c}{ Fraction of Precipitation (\%) } \\
\cline { 2 - 7 } & Andaraí & Iguaçu & Fortém & Andaraí & Iguaçu & Fortém \\
\hline Precipitation & 866.5 & 701.2 & 784.3 & - & - & - \\
Evapotranspiration & 599.8 & 541.4 & 675.0 & 69.2 & 77.2 & 86.1 \\
Runoff & 96.7 & 38.7 & 28.5 & 11.2 & 5.5 & 3.6 \\
Lateral flow & 76.5 & 52.8 & 37.8 & 8.8 & 7.5 & 4.8 \\
Base flow & 48.0 & 40.7 & 20.6 & 5.5 & 5.8 & 2.6 \\
Soil storage & 45.5 & 27.6 & 22.4 & 5.3 & 3.9 & 2.9 \\
\hline
\end{tabular}

Table 10. Minimum and actual annual actual evapotranspiration values in Andaraí, Iguaçu and Fortém per land use.

\begin{tabular}{clccccccc}
\hline \multirow{2}{*}{ Basin } & Range & PAST & SWRN & $\begin{array}{c}\text { FRST } \\
\text { Annual Actual }\end{array}$ & $\begin{array}{c}\text { FRSD } \\
\text { Evapotranspiration (mm) }\end{array}$ & $\begin{array}{c}\text { RNGE } \\
\text { RNGB }\end{array}$ & AGRR \\
\hline \multirow{2}{*}{ Andaraí } & Minimum & 324 & 312 & 255 & 284 & 314 & 278 & 562 \\
& Maximum & 1040 & 723 & 1222 & 1227 & 725 & 719 & 810 \\
\multirow{2}{*}{ Iguaçu } & Minimum & 200 & 210 & 143 & 177 & 182 & 191 & 537 \\
& Maximum & 991 & 646 & 1044 & 1042 & 644 & 643 & 727 \\
Fortém & Minimum & 252 & 303 & 228 & 243 & 301 & 278 & 253 \\
& Maximum & 1294 & 1112 & 1411 & 1420 & 1107 & 774 & 1097 \\
\hline
\end{tabular}

PAST, pasture; SWRN, caatinga; FRST, mixed forest; FRSD, deciduous forest; RNGE, cerrado, RNGB, bushes cerrado; AGRR, agricultural land.

\subsection{Estimate of Maximum, Average and Minimum Monthly Streamflow}

Figure 7 shows results of the regression analysis between monthly simulated and observed streamflow from the 1989-2013 period, with data separated by quartiles. The regression coefficient evidenced that the model tended to overestimate minimum streamflow between $4-7 \%$ (Figure 7(A1,B1,C1), the first quartile). The model also underestimated the average (Figure 7(B1,B2,B3), the second quartile) and maximum (Figure $7(\mathrm{C} 1, \mathrm{C} 2, \mathrm{C} 3)$, the third quartile) streamflow in all stations between $4-17 \%$. Likewise, Table 11 shows the results of the paired $t$-test and regression analysis to observed and simulated monthly streamflow, also separated by quartiles. Differences between observations and simulations were not significant for first, second and third quartiles, except for Fortém station 2nd and 3rd quartiles. These results showed that the SWAT model can be used for the estimation of maximum, average and minimum monthly streamflow in this sub-basin, with potential use in hydrological studies and water management.

The analysis of the SWAT model results for improving management and planning of streamflow is usually also carried out by analyzing maximum, minimum and reference flow based on historical series [44]. The availability of hydrological data in the Paraguaçu watershed and other semiarid regions of Brazil is quite limited or even nonexistent, which makes the definition of a reference flow a difficult task when models are not used, thus enhancing the interest of the outcomes of this study as a valuable alternative. The permanence curve is one of the available tools to determine water availability in a river basin. Figure 8 shows the observed and simulated permanence curves given by the model in the calibration and validation stages for the period 1989 to 2013, on a monthly scale. 
The flow duration curves show that the model underestimated higher flows than lower ones in Andaraí, Iguaçu and Fortém. For example, the curve for simulated monthly data closely matched the observed evidence for exceedance probabilities of $<90 \%$. However, for streamflows with exceedance values $>90 \%$ (i.e., low flows), apparent differences in predictive capabilities were evident. In all the sub-basins, flows with exceedance values Q90\% and $95 \%$ were overestimated at maximum $24 \%$ and $16 \%$, respectively (Table 12). The maximum error found for flows with exceedance values Q90\% was for the Andaraí sub-basin, which has the largest irrigated area generating more uncertainties in the Q90\% estimate due to farmers' irrigation management at the plot scale, which remains partially unknown. In general, errors were of small magnitude for other areas. It was possible to verify that the SWAT model adequately simulated flow duration curves for the three sub-basins of the Paraguaçu watershed, demonstrating its quality as an auxiliary tool in water resources management. The model errors observed while simulating minimum and reference flows were within a range considered acceptable in hydrology [45]. However, errors in simulating maximum extreme values, which came close to $50 \%$, indicated non-suitability of the model for estimating extreme events, precluding its use in dimensioning flood control infrastructure. Pereira et al. [45] stated that errors up to $30 \%$ in simulated flow are considered satisfactory for the concession of water use in irrigated areas of Brazil. Therefore, the SWAT model results in this study can be used for improving management and planning of streamflows at the watershed scale.
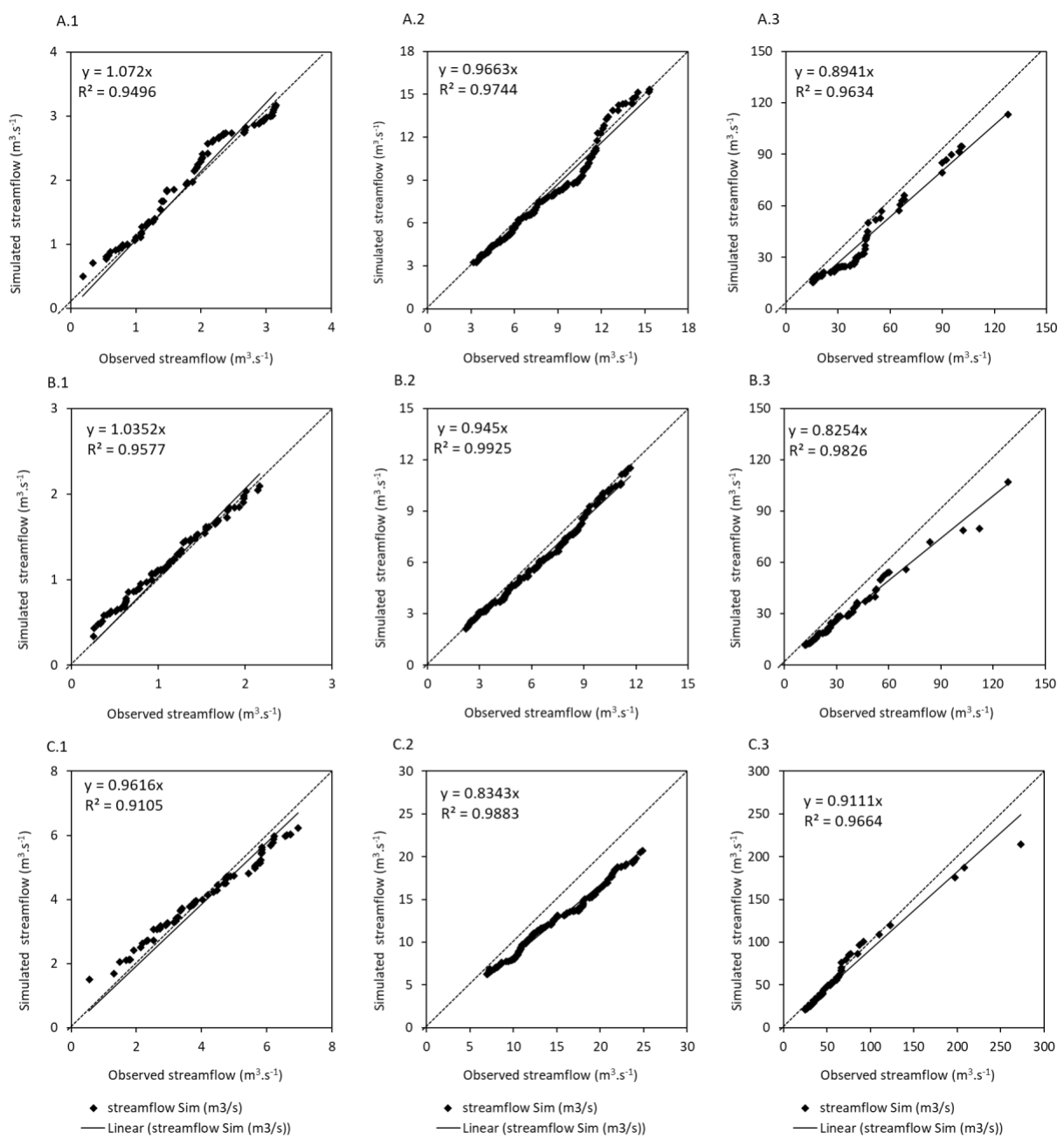

Figure 7. Regression analysis between monthly simulated and observed streamflow among 1989-2013 separated for quartile (1—first, 2—second and 3-third quartiles). Sub-basins: Andaraí (A), Iguaçu (B) and Fortém (C). 
Table 11. Results of the regression analysis and paired $t$-test on observed and simulated average monthly (1989-2013).

\begin{tabular}{ccccccc}
\hline Fluviometric Station & Quartile & $\mathbf{n}$ & $\mathbf{a}$ & $\mathbf{t}_{\text {cal }}$ & $\mathbf{t}_{\text {crit }}$ & $\mathbf{R}^{\mathbf{2}}$ \\
\hline \multirow{3}{*}{ Andaraí } & $1^{\mathrm{o}}$ & 71 & 0.89 & $1.14^{(\mathrm{ns})}$ & 1.977 & 0.96 \\
& $2^{\circ}$ and $3^{\mathrm{o}}$ & 140 & 0.97 & $0.79^{(\mathrm{ns})}$ & 1.968 & 0.97 \\
& $4^{\mathrm{o}}$ & 70 & 1.07 & $-1.37^{(\mathrm{ns})}$ & 1.977 & 0.95 \\
\multirow{2}{*}{ Iguaçu } & $1^{\mathrm{o}}$ & 74 & 0.82 & $1.42^{(\mathrm{ns})}$ & 1.976 & 0.98 \\
& $2^{\mathrm{o}}$ and $3^{\mathrm{o}}$ & 148 & 0.95 & $1.13^{(\mathrm{ns})}$ & 1.978 & 0.99 \\
& $4^{\mathrm{o}}$ & 74 & 1.04 & $-0.94^{(\mathrm{ns})}$ & 1.976 & 0.96 \\
\multirow{2}{*}{ Fortém } & $1^{\mathrm{o}}$ & 68 & 0.91 & $0.59^{(\mathrm{ns})}$ & 1.978 & 0.97 \\
& $2^{\circ}$ and $3^{\mathrm{o}}$ & 133 & 0.83 & $4.16^{*}$ & 1.969 & 0.99 \\
& $4^{\mathrm{o}}$ & 67 & 0.96 & $0.12^{(\mathrm{ns})}$ & 1.978 & 0.91 \\
\hline
\end{tabular}

$\mathrm{n}$-number of sample value; a-regression coefficient; $\mathrm{t}_{\text {cal }}$-paired $t$-test, calculated value; $\mathrm{t}_{\text {crit }}$-paired $t$-test, two-tailed value; ns-not significant at $5 \%$ level of significance; ${ }^{*}$ significant at the $5 \%$ level of significance.

a

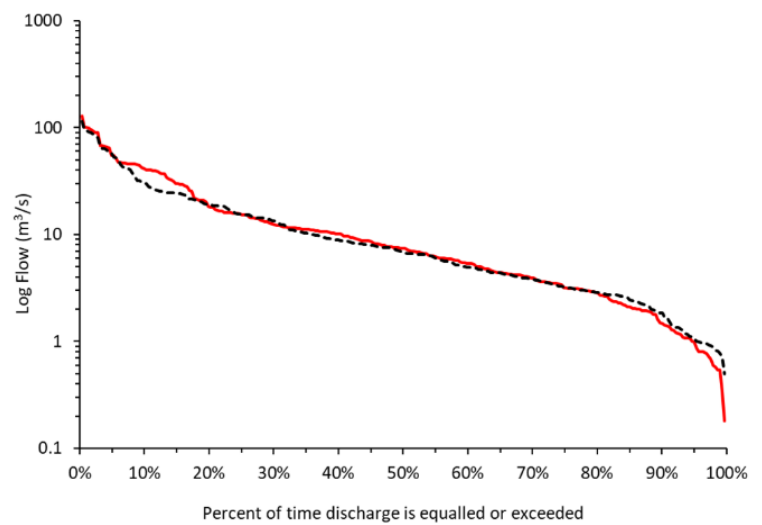

b
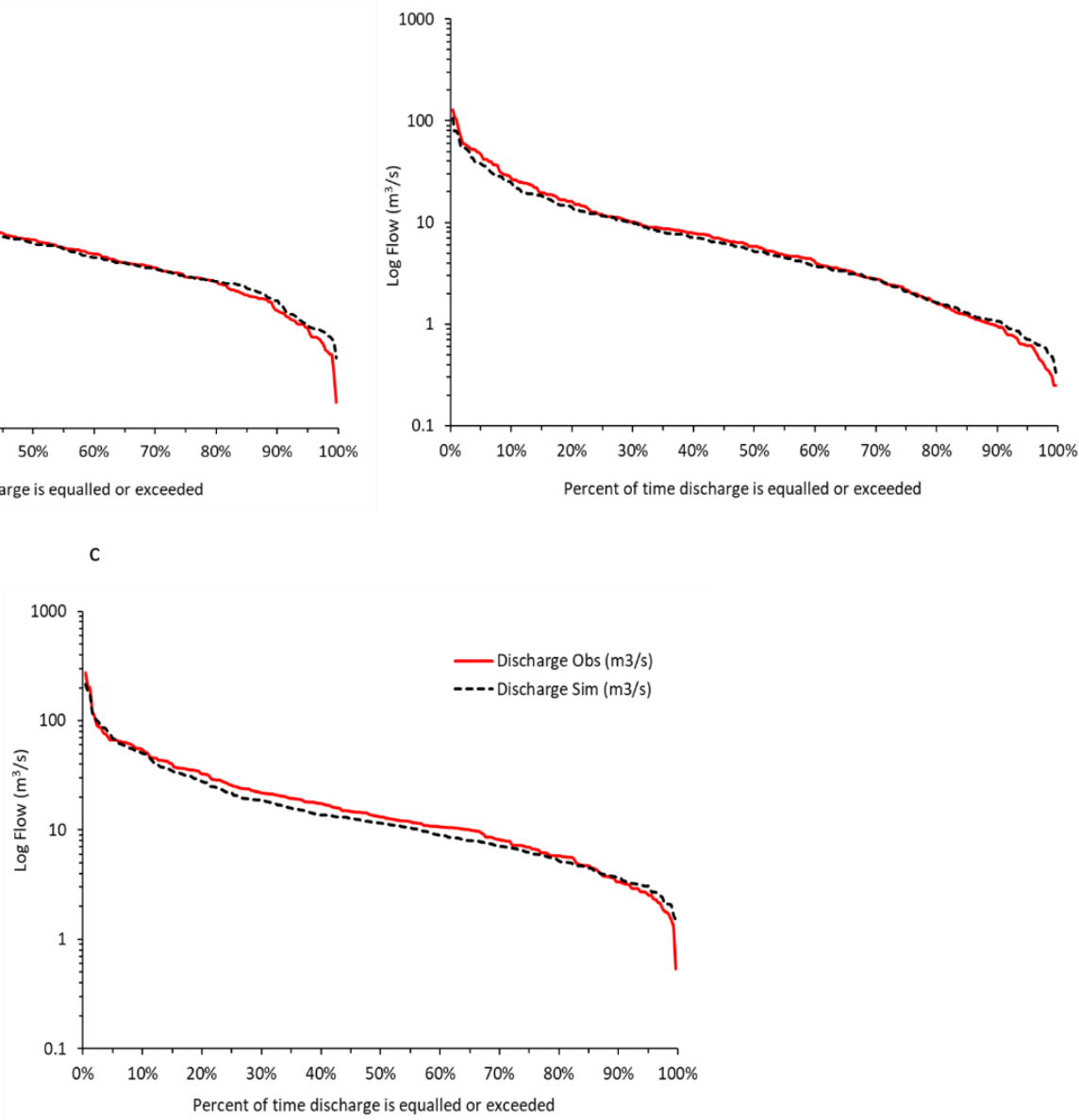

Figure 8. Observed and simulation monthly flow curves in Andaraí (a), Iguaçu (b) and Fortém (c) sub-basins. 
Table 12. Comparison exceedance Q90 and Q95 values between observed and simulated monthly flow for the period to 1989-2013.

\begin{tabular}{ccccccc}
\hline \multirow{2}{*}{ Station } & \multicolumn{3}{c}{$\mathbf{9 0 \%}$ Exceedance } & \multicolumn{3}{c}{$\mathbf{9 5 \%}$ Exceedance } \\
\cline { 2 - 7 } & $\mathbf{Q}_{\text {obs }}$ & $\mathbf{Q}_{\text {sim }}$ & Error (\%) & $\mathbf{Q}_{\text {obs }}$ & $\mathbf{Q}_{\text {sim }}$ & Error (\%) \\
\hline Andaraí & 1.47 & 1.83 & 24.0 & 0.98 & 1.0 & 8.0 \\
Fortém & 3.38 & 3.66 & 8.0 & 2.63 & 3.0 & 16.0 \\
Iguaçu & 0.97 & 1.07 & 10.0 & 0.61 & 0.70 & 14.0 \\
\hline
\end{tabular}

\section{Conclusions}

The SWAT model was able to reproduce long-term daily and monthly streamflow in the Paraguaçu watershed, northeastern Brazil, including nonstationary conditions and seasonality between wet and dry years. The goodness-of-fit indicators resulted in NSE values higher than 0.42 and 0.76 for daily and monthly streamflow, respectively, indicating a satisfactory performance at the daily scale and an excellent result at the monthly scale. The hierarchical calibration approach further showed that the calibrated parameters were transferable to other sub-basins with similar land use, being thus capable of predicting the impact of land use change at the watershed scale. Likewise, the regression analysis and paired $t$-test showed that the SWAT model was fit for estimating the maximum, average, minimum monthly streamflow in the studied sub-basins, with potential use in hydrological studies and water management plans. On the other hand, the flow duration curves showed that the model can be used as an auxiliary tool in the management of streamflow, with the model underestimating higher flows that result from extreme events but performing well for flows with exceedance probabilities of $<90 \%$. As such, the curve flows associated with different exceedances, especially Q90\%, attested the applicability of the model as a tool for management and planning of streamflow in the three sub-basins of the Paraguaçu watershed.

Author Contributions: C.A.S. Santos set up the model, run the simulations and wrote the paper. The other authors made revisions and improvements to the draft version.

Funding: Acknowledges are due to the Institute Federal of Bahia. MARETEC acknowledges ERDF Funds of the Competitiveness Factors Operational Programme-COMPETE-and national funds from the Fundação para a Ciência e Tecnologia (FCT) (Project UID/EEA/50009/2013). T.B. Ramos was funded by FCT funds (SFRH/BPD/110655/2015).

Conflicts of Interest: The authors declare no conflict of interest.

\section{References}

1. Silva, S.F. Análise da disponibilidade e demanda para o sistema de abastecimento de água de salvador frente a cenário de mudanças climáticas. Master's Thesis, Universidade Federal da Bahia, Salvador, Brazil, 2012.

2. Yu, X.; Duffy, C.J. Watershed hydrology: scientific advances and environmental assessments. Water 2018, 10, 288. [CrossRef]

3. Zeiger, S.J.; Hubbart, J.A. Assessing environmental flow targets using pre-settlement land cover: A SWAT modeling application. Water 2018, 10, 791. [CrossRef]

4. Yevenes, M.A.; Mannaerts, C.M. Seasonal and land use impacts on the nitrate budget and export of a mesoscale catchment in southern Portugal. Agric. Water Manag. 2011, 102, 54-65. [CrossRef]

5. Brito, D.; Neves, R.; Branco, M.C.; Gonçalves, M.C.; Ramos, T.B. Modeling flood dynamics in a temporary river draining to an eutrophic reservoir in southeast Portugal. Environ. Earth Sci. 2017, 76, 377. [CrossRef]

6. Neitsch, S.L.; Arnold, J.G.; Kiniry, J.R.; Williams, J.R. Soil and Water Assessment Tool Theoretical Documentation Version 2009; Technical Report No.406; Texas Water Resources Institute: Forney, TX, USA, 2011.

7. de Souza Dias, V.; Pereira da Luz, M.; Medero, G.M.; Tarley Ferreira Nascimento, D.; Nunes de Oliveira, W.; Rodrigues de Oliveira Merelles, L. Historical streamflow series analysis applied to Furnas HPP reservoir watershed using the SWAT model. Water 2018, 10, 458. [CrossRef] 
8. Sánchez-Pérez, J.M.; Vervier, P.; Garabétian, F.; Sauvage, S.; Loubet, M.; Rols, J.L.; Bariac, T.; Weng, P. Nitrogen dynamics in the shallow groundwater of a riparian wetland zone of the Garonne, SW France: Nitrate inputs, bacterial densities, organic matter supply and denitrification measurements. Hydrol. Earth Syst. Sci. 2003, 7, 97-107. [CrossRef]

9. Oeurng, C.; Sauvage, S.; Sánchez-Pérez, J.M. Temporal variability of nitrate transport through hydrological response during flood events within a large agricultural catchment in South-West France. Sci. Total Environ. 2010, 409, 140-149. [CrossRef] [PubMed]

10. Klemeš, V. Operational testing of hydrological simulation models. Hydrol. Sci. J. 1986, 31, 13-24. [CrossRef]

11. Arnold, J.G.; Moriasi, D.N.; Gassman, P.W.; Abbaspour, K.C.; White, M.J.; Srinivasan, R.; Santhi, C.; Harmel, R.D.; van Griensven, A.; Van Liew, M.W.; et al. SWAT: Model use, calibration and validation. Am. Soc. Agric. Biol. Eng. 2012, 55, 1491-1508.

12. Fisher, R.A. Statistical Methods for Research Workers, 8th ed.; Oliver and Boyd: Edinburgh, UK, 1941.

13. Instituto do Meio Ambiente e Recursos Hídricos. Comitê da bahia hidrográfica do paraguaçu. Available online: http:/ / www.inema.ba.gov.br/gestao-2/comites-de-bacias/comites/cbh-paraguacu/ (accessed on 24 August 2018).

14. Embrapa. Solo brasileiro agora tem mapeamento digital. Available online: https://www.embrapa.br/web/ portal/busca-de-noticias/- / noticia/2062813/solo-brasileiro-agora-tem-mapeamento-digital (accessed on 24 August 2018).

15. Allen, R.G.; Pereira, L.S.; Raes, D.; Smith, M. Crop Evapotranspiration-Guidelines for Computing Crop Water Requirements; FAO Irrigation and Drainage Paper 56; Food and Agriculture Organization of the United Nations: Rome, Italy, 1998.

16. Ritchie, J.T. Model for predicting evaporation from a row crop with incomplete cover. Water Resour. Res. 1972, 8, 1204-1213. [CrossRef]

17. United States Department of Agriculture. Estimation of direct runoff from storm rainfall. In National Engineering Handbook; United States Department of Agriculture: Washington, DC, USA.

18. Agência Nacional de Água. Orientações para elaboração de estações hidrométricas; Agência Nacional de Água: Brasília, Brazil, 2011.

19. Xavier, A.C.; King, C.W.; Scanlon, B.R. Daily gridded meteorological variables in Brazil (1980-2013). Int. J. Clim. 2015, 36, 2644-2659. [CrossRef]

20. Instituto do Meio Ambiente e Recursos Hídricos (INEMA). NOTA TÉCNICA GVIMS/GGTES/ANVISA N ${ }^{o}$ 01/2015; Instituto do Meio Ambiente e Recursos Hídricos (INEMA): Salvador, Brazil, 2015; p. 12.

21. Silva, R.M.; Medeiros, I.C. Análise hidrossedimentológica em ambiente SIG usando o modelo SWAT. GeoFocus 2014, 14, 211-231. Available online: http://geofocus.rediris.es/2014/Articulo11_2014.pdf (accessed on 24 August 2018).

22. Xavier, F.V. Contribuições metodológicas ao estudo da produção e distribuição espacial de sedimentos na bacia hidrográfica do rio manso, utilizando o modelo avswat. Master's Thesis, Universidade Federal de Mato Grosso, Cuiabá, Brazil, 2009.

23. Mercuri, E.G.F.; Deppe, F.; Lohmann, M.; Simões, K. Metodologia da geração de dados de entrada e aplicação do modelo SWAT para bacias hidrográficas brasileiras. In Anais XIV Simpósio Brasileiro de Sensoriamento Remoto; Instituto Nacional De Pesquisas Espaciais: Natal, Brasil, 2009; pp. 4773-4780.

24. Santana, S.O.; Santos, R.D.; Gomes, I.A.; Jesus, R.M.d.; Araujo, Q.R.d.; Mendonça, J.R.; Calderano, S.B.; Farias Filho, A.F. Solos da região sudeste da bahia: Atualização da legenda de acordo com o sistema brasileiro de classificação de solos; Embrapa Solos: Rio de Janeiro, Brasil, 2002; pp. 1-93.

25. Bontemps, S.; Defourny, P.; Radoux, J.; Bogaert, E.V.; Lamarche, C.; Achard, F.; Mayaux, P.; Boettcher, M.; Brockmann, C.; Kirches, G.; et al. Globcover 2009 Product Description and Validation Report. 18 February 2011. Available online: http://due.esrin.esa.int/files/GLOBCOVER2009_Validation_Report_ 2.2.pdf (accessed on 24 August 2018).

26. IBGE. Produção agrícola municipal. Available online: https://ww2.ibge.gov.br/home/estatistica/ pesquisas / pesquisa_resultados.php?id_pesquisa=44 (accessed on 10 June 2015).

27. $\mathrm{Xu}, \mathrm{C} . \mathrm{Y}$. Operational testing of a water balance model for predicting climate change impacts. Agric. For. Meteorol. 1999, 98-99, 295-304. [CrossRef]

28. Nash, J.E.; Sutcliffe, J.V. River flow forecasting through conceptual models part I-A discussion of principles. J. Hydrol. 1970, 10, 282-290. [CrossRef] 
29. Moriasi, D.N.; Arnold, J.G.; Van Liew, M.W.; Bingner, R.L.; Harmel, R.D.; Veith, T.L. Model evaluation guidelines for systematic quantification of accuracy in watershed simulations. Trans. ASABE 2007, 50, 885-900. [CrossRef]

30. Veith, T.L.; Van Liew, M.W.; Bosch, D.D.; Arnold, J.G. Parameter sensitivity and uncertainty in SWAT: A comparison across five USDA-ARS watersheds. Trans. ASABE 2010, 53, 1477-1486. [CrossRef]

31. Vieira, M.S.B.; Machado, E.C.M.N.; Furtunato, O.M. Análise de padrões de precipitação através da variabilidade espacial na bacia hidrográfica do rio paraguaçu. In Proceedings of the XIV Congresso Mundial da Água, Porto de Galinhas, Brazil, 25-29 September 2011.

32. Cho, J.; Bosch, D.; Lowrance, R.; Strickland, T.; Vellidis, G. Effect of spatial distribution of rainfall on temporal and spatial uncertainty of SWAT output. Trans. ASABE 2009, 52, 1545-1556. [CrossRef]

33. Awotwi, A.; Kumi, M.; Jansson, P.E.; Yeboah, F.; Nti, I.K. Predicting hydrological response to climate change in the White Volta catchment, West Africa. J. Earth Sci. Clim. Change 2015, 6, 1-7.

34. Nie, W.; Yuan, Y.; Kepner, W.; Erickson, C.; Jackson, M. Hydrological impacts of mesquite encroachment in the upper San Pedro watershed. J. Arid Environ. 2012, 82, 147-155. [CrossRef]

35. Pereira, D.D.R.; Martinez, M.A.; Pruski, F.F.; Silva, D.D.D. Hydrological simulation in a basin of typical tropical climate and soil using the SWAT model part I: Calibration and validation tests. J. Hydrol. Reg. Stud. 2016, 7, 14-37. [CrossRef]

36. von Stackelberg, N.O.; Chescheir, G.M.; Skaggs, R.W.; Amatya, D.M. Simulation of the hydrologic effects of afforestation in the Tacuarembó river basin, Uruguay. Trans. ASABE 2007, 50, 455-468. [CrossRef]

37. Muleta, M.K. Improving model performance using season-based evaluation. J. Hydrol. Eng 2012, 17, 191-200. [CrossRef]

38. Li, H.; Sivapalan, M.; Tian, F. Comparative diagnostic analysis of runoff generation processes in Oklahoma DMIP2 basins: The Blue River and the Illinois River. J. Hydrol. 2012, 418-419, 90-109. [CrossRef]

39. Lévesque, É.; Anctil, F.; Van Griensven, A.N.N.; Beauchamp, N. Evaluation of streamflow simulation by SWAT model for two small watersheds under snowmelt and rainfall. Hydrol. Sci. J. 2008, 53, 961-976. [CrossRef]

40. Pilgrim, D.H.; Chapman, R.G.; Doran, D.G. Problems of rainfall-runoff modelling in arid and semiarid regions. Hydrol. Sci. J. 1988, 33, 379-400. [CrossRef]

41. Gao, F.; Feng, G.; Ouyang, Y.; Wang, H.; Fisher, D.; Adeli, A.; Jenkins, J. Evaluation of reference evapotranspiration methods in arid, semiarid and humid regions. J. Am. Water Resourc. Assoc. 2017, 53, 791-808. [CrossRef]

42. Santos, C.A.G.; Marques da Silva, R.; Silva, A.M.; Neto, R.M.B. Estimation of evapotranspiration for different land covers in a Brazilian semi-arid region: A case study of the Brígida River basin, Brazil. J. S. Am. Earth Sci. 2017, 74, 54-66. [CrossRef]

43. Bouraoui, F.; Benabdallah, S.; Jrad, A.; Bidoglio, G. Application of the SWAT model on the Medjerda river basin (Tunisia). Phys. Chem. Earth 2005, 30, 497-507. [CrossRef]

44. Viola, M.R.; Mello, C.R.; Acerbi, F.W., Jr.; da Silva, A.M. Hydrologic modeling in the Aiuruoca river basin, Minas Gerais State. Rev. Bras. Eng. Agríc. Ambient. 2009, 13, 581-590. [CrossRef]

45. Pereira, D.D.R.; Martinez, M.A.; Almeida, A.Q.; Preuski, F.F.; Silva, D.D.; Zonta, J.H. Hydrological simulation using SWAT model in headwater basin in Southeast Brazil. Eng. Agríc. 2014, 34, 789-799. [CrossRef]

(C) 2018 by the authors. Licensee MDPI, Basel, Switzerland. This article is an open access article distributed under the terms and conditions of the Creative Commons Attribution (CC BY) license (http:/ / creativecommons.org/licenses/by/4.0/). 